Даница С. Сладојевић ${ }^{1}$

Универзитет у Ниму

Филозофски факултет
УДК 371.3::821.163.41.09 Киш Д.

Прегледни научни рад

Примљен: 18. фебруар 2021.

Прихваћен: 5. април 2021.

DOI: https://doi.org/10.46630/gsrj.19.2021.19

\title{
АУТОБИОГРАФСКИ ПРИСТУП У НАСТАВНОМ ПРОУЧАВАНУ РАНИХ ЈАДА ДАНИЛА КИША
}

\begin{abstract}
Рад има за циљ да теоријски представи могућност другачијег приступа у наставном проучавању Раних јада Данила Киша, не одричући стандардним приступима вредност, али указујући на њихову већ увелико изгубљену оригиналност. Обиље факата из живота творца Раних јада уграђено је у искидана сећања књижевног јунака Андреаса Сама који ће успешно, мада на тренутке несигурним корацима, кренути у сусрет свом детињству. Чија су то сећања и да ли је могуће "позајмити" их књижевном јунаку а остати неутралан, само су неки од проблема који ученике могу подстаћи на готово филозофска размишљања.
\end{abstract}

Кључне речи: наставно проучавање романа, аутобиографски приступ, Данило Киш, Рани јади

\section{1. Увод}

Проучавање Раних јада Данила Киша смештено је у оквире наставног програма за први разред средње школе. По многим својим карактеристикама, а и по времену свога настанка, ово дело припада модерној српској књижевности, те има задатак да разбије извесну монотонију проучавања књижевности старог и средњег века, ученицима често неприступачних због велике временске удаљености. Међутим, и поред тога што је ученицима ближа, проза Данила Киша поседује комплексност и чини поље још увек отворено за проучавање, што може додатно отежати тумачење. Класичан приступ подразумева краћи осврт на пишчеву биографију, уочавање жанровске хибридности, смештање у одговарајући историјски контекст и фокусирање на чула и осећаје који, мора се признати, заузимају битно место у композицији самог дела.

Ниједан од поменутих чинилаца не може се окарактерисати као сувишан или занемарљив, али то не искључује могућност иновирања начина поступања приликом тумачења дела Данила Киша или макар могућност његове модификације. У овом раду ћемо покушати да прићемо Андреасу Саму преко његовог творца, али тако да не нарушимо аутентичност ни

\footnotetext{
${ }^{1}$ danica.ng@hotmail.com
} 
лика ни личности. Зато ћемо приступ назвати аутобиографским, а као ослонац ће нам послужити Аутобиографија Данила Киша, обимна студија о Раним јадима Јована Делића, али и жива пишчева реч присутна у многим интервјуима објављеним на интернету или пак сакљупеним у књизи Горки талог искуства.

\section{2. Наставни циљеви}

Остваривање образовних, васпитних и практичних задатака има за циљ да ученицима омогући потпун и јединствен доживљај књижевног дела. Да би се то заиста и остварило, они се морају прецизно формулисати.

Образовни задаци, приликом тумачења Раних јада, пре свега би подразумевали: проширивање знања о пишчевој биографији и његовом стваралачком опусу (овај задатак не би захтевао од ученика памћење година и већ свима добро познатих детаља из живота Данила Киша, већ сагледавање оних тренутака који се могу довести у, посредну или непосредну, везу са његовим књижевним делом); упознавање ученика са мешањем жанрова као једном од битних одлика модерне књижевности на примеру Раних јада Данила Киша; упознавање ученика са фрагментарном композицијом као једном од битних одлика прозе Данила Киша, али и сагледавање њене узрочности; уочавање промене перспектива у приповедању и сагледавање основне функције овог књижевног поступка; разграничење фикционалног и фактографског у Раним јадима Данила Киша; сагледавање поступка преобликовања чињеничног у литерарно у Раним јадима Данила Киша.

Ови образовни задаци повлаче за собом васпитне, као што су: развијање код ученика разумевања за друге и другачије, „децу и осетљиве”; преиспитивање и вредновање етичких норми које су важиле у некадашњим ратним околностима; подстицање ученика на неговање успомена као битних чинилаца човековог живота; обогаћивање ученичког читалачког искуства и подстицање на даље читање.

Практични задаци би обухватали: оспособљавање ученика за уочавање специфичних поступака у уобличавању једног књижевног дела, затим за успешно разграничавање чињеничног од фиктивног, али и за уочавање стварносног у литерарном, а све то на примеру Раних јада Данила Киша. Ту је затим и њихово оспособљавање за самосталан истраживачки рад, као и за самостално вредновање како дела, тако и различитих животних ситуација са којима се сусрећу. Као један од битних практичних задатака био би и оспособљавање ученика за уочавање веза између претходно рађеног и новог градива. 


\section{3. О делу и приступу}

Иако се Рани јади појављују након романа Башта, пепео, а пре Пешчаника, они се и по свом садржају, али и по речима самог писца узимају као почетак, тачније први део породичног циклуса, „својеврсне трилогије”, како ју је управо Данило Киш називао. Оно што Ране јаде чини делом савремене српске књижевности јесте, пре свега, жанровска неодређеност. Због своје специфичне композиције, они збуњују читаоца и наводе га на закључак да у својим рукама држи збирку кратких прича или приповедака. С друге стране, смештене у контекст породичне трилогије, обједињене главном личношћу дечака и идејом коју са собом носе, приче се разобличавају и прерастају у искидана поглавља романа, садржине готово целе исприповедане из перспективе једног детета. Јасно је да је тај дечак, Андреас Сам, књижевни лик. Међутим, није га увек лако одвојити од личности његовог творца.

Поводом двадесет и пете године од смрти Данила Киша, Трећи програм Радио Београда репризирао је разговор који је 1987. године са писцем водила Радмила Глигић ${ }^{2}$. У најави овог интервјуа, поменута новинарка истиче један од занимљивих ставова писца, по коме су читаоци, постојећи и могућни, саучесници књижевног дела. Ако, као такви, уписујемо себе у странице прочитане књиге и бивамо саучесници у описаним догађајима, понекад чак и злочинима, онда је могуће у исписаним редовима пронаћи и самога писца.

У наставном проучавању Раних јада, као што је у уводу већ речено, честа полазишта везана су за мирисе и боје, приказ детињства, умножавање перспектива. Понекад се професори дотакну и пишчеве биографије, али ретко тако да је доведу у тесну везу са написаним, што је и разумљиво с обзиром на то да се биографски приступ често осуђује као неадекватан и превазиђен, такав да води у биографизирање. Међутим, примењен на адекватан начин, он не може бити погрешан, посебно када је у питању дело које обилује чињеницама из стварног пишчевог живота. Оне се, наравно, не уносе у дело непрерађене и готове, већ пролазе кроз известан процес „субјективизације”, уз чију помоћ већим својим делом постају књижевне, а мањим остају биографске. Пронаћи у њима биографско значило би додатно их осветлити, непристојно, али и са поштовањем, продрети у лични простор писца, сузити, али и продубити доживљено.

\section{4. Припрема ученика за час обраде Раних јада}

Припрема за час обраде Раних јада могла би да обухвати одређене истраживачке задатке који би били у вези са пишчевом биографијом и делом, а који би олакшали тумачење и учинили га економичнијим. Ти задаци би

\footnotetext{
${ }^{2}$ https://www.youtube.com/watch?v=c2nWD_Sbuxs [11. 11. 2019]
} 
омогућили уочавање повезаности, али и разлика између описаног и стварно доживљеног.

С обзиром на то да су у основној школи радили радио-драму Hoћ $u$ магла Данила Киша, било би добро да је ученици поново одслушају, не зато што је у питању дело истог писца, већ зато што је главни јунак ове драме управо Андреас Сам, који као одрастао човек долази у посету својој учитељици. Пошто је у питању још једно путовање у прошлост, ученици ће имати додатни задатак да забележе главну мисао о успоменама која се помиње на неколико места у тексту. Став да су успомене у ствари „дим, пара, сан, магла, ништа" битан је и за Ране јаде, који су у ствари почетак исцрпљујућег лутања по сећањима у којима је писац заједно са нашим малим јунаком тражио себе, али и свога оца.

У вези са Раним јадима требало би наговестити да је неопходно обратити пажњу на композицију, јер је фрагментарност та која стоји у директној корелацији са искиданим успоменама. Самим тим, кратке приче ове збирке или, другачије, поглавља овог романа не чине хронолошки уоквирену целину, већ низ догађаја који су из одређених разлога остали у живом нараторовом сећању. Па ипак, ти фрагменти из живота Андреаса Сама нису без икаквог реда и поретка. Говорећи о Раним јадима, Јован Делић често напомиње значај који „синтакса” има у делу Данила Киша, истиче строги и нужни след прича/поглавља, које се на посебан начин надовезују једна на другу.

Неопходно је, такође, обратити пажњу и на наслов, а посебно на поднаслов Раних јада, јер и један и други имају изразиту сугестивну моћ. Та иста моћ приписује се и називу Ноћ и магла, који није нимало случајно употребљен. Следећи корак био би разговор о делу на самом часу.

\section{5. Разговор о роману на часу}

Разговору са ученицима претходило би пуштање видео-снимка у коме глумац Мики Манојловић у улози Данила Киша уводи проблем писања као тражења сопствене личности, сопственог ја, у свету детињства или себи самом. ${ }^{3}$ Након тога уследило би пуштање другог снимка, конкретније аудиоснимка „извода из књиге рођених”, односно „кратке аутобиографије” писца, коју говори сада Киш без посредника. У чињеницама које аутор о себи износи могуће је препознати оне које се сусрећу у Раним јадима, а потрага за самим собом у књижевности надовезаће се на друге пишчеве изјаве које потврђују уношење личног и истинитог у његова књижевна дела. Иако преузете из стварног живота, врло је лако уочити, а то је битно и ученицима нагласити, да су оне до извесне мере прерађене, тј. преобликоване тако да су постале

\footnotetext{
${ }^{3}$ https://www.youtube.com/watch?v=CP3nylnyico\&t=151s (део 2:03-2:54) [11. 11. 2019]
} 
књижевне, такве да их није лако увек међусобно повезати и да је дело, као што су и сами осетили док су читали, могуће доживети и без њиховог познавања. Међутим, њихово разоткривање би било вишеструко корисно, а пре свега би послужило за расветљавање нејасних места и попуњавање празнина које су неминовне када се говори о успоменама надограђенима уз помоћ пишчеве маште.

Књига под називом Горки талог искуства, чију синтагму из наслова чујемо и у речима Микија Манојловића, а која представља избор из разговора које је Данило Киш водио са домаћим и страним новинарима, па и књижевним критичарима, у раздобљу од 1972. до 1989. године, а чији је приређивач пишчева прва супруга, прошарана је, такође, аутобиографским подацима, те је и њу могуће искористити. Те податке је, како Мирјана Миочиновић наводи у поговору, „Kiš iznosio ne samo da bi udovoljio znatiželji sagovornika (a preko ovih i znatiželji svojih čitalaca), već i zato što ga je trajno zaokupljalo pitanje odnosa između fikcije i fakata, između opisanog i opisivača, između literature i života" (KIŠ 2007: 359). Због тога, могуће је искористити и неке од занимљивијих одговора које је Данило Киш дао својим сабеседницима на њихова исто тако интересантна питања.

У интервјуу који се у овој књизи наводи под насловом Живот, литература, Данило Киш на питање о уделу аутобиографског у својим књигама каже да је „форма” у којој је предочио своје детињство постала саставни део његовог детињства, заправо једино његово детињство: „I ја sam sad i sam jedva u stanju da napravim razliku između te dve iluzije, između životne i književne istine; one se prožimaju u tolikoj meri da tu povući jasnu granicu jedva da je mogućno" (KIŠ 2007: 236). Па ипак, писац исто тако сматра да се живот не може свести на књиге, нити се књиге могу свести на живот. Оба та приступа би представљала неки вид редукционизма, самим тим осиромашења једног или другог. Да не би до тога дошло, морали бисмо водити рачуна о томе да његово дело осветлимо са више страна, узимајући у обзир животне чињенице као релевантне, али не и једино релевантне.

Тај однос између животне и књижевне истине, однос напетости који је мучио готово целога живота нашег писца, требало би пренети на ученике, учинити да осете благу збуњеност и двоумљење, како би се заинтересовали и укључили у разговор који би им омогућио да креиране недоумице отклоне. Проблемска ситуација која на тај начин настаје подстиче на, можемо их слободно тако назвати, филозофска размишљања. Неоспорно је да писци увек крећу од стварног, реалног, али не увек и личног. Способност једног уметника да одређени доживљај предочи као свој, иако то није, способност да се емпатички повеже са другима, чини од њега великог ствараоца. Па ипак, користећи „погубно прво лице”, како га је сам Киш називао, књижевник прво што чини код својих читалаца јесте буђење сумње да говори о себи. Тај бег од свог, од сопственог код творца Раних јада уочљив је у непрестаној 
смени лица, сужавању и ширењу перспективе, мењању угла из кога невидљива камера прати главног јунака Андреаса Сама и његове суђене и несуђене сапутнике. Колико је успешан био тај пишчев бег видљиво је из већ наведених његових речи којима тврди да ни сам није био у стању да прави јасну разлику између написаног и стварно доживљеног и да је, поред свега, у својим делима ипак тражио себе самог.

Кренути сада треба од самог наслова и поднаслова. Након прочитане књиге, није тешко закључити да се наслов неоспорно односи на прве утиске о свету у коме се дечак нашао, на уочавање несклада између слике ствари и њихове суштине, на чињеницу да „детињство није никакво срећно доба, већ доба јада; доба првих и великих искустава зла и патње; искуства смрти и губитака, од којих је, свакако, највећи и најзначајнији губитак оца; губитак који је рано и снажно поставио пред дјечака питање идентитета" (ДЕЛИЋ 1997: 68). Поднаслов сугерише да Рани јади нису дело које је намењено свима. Лирска компонента јако је наглашена, а утисци који су најчешће предочени из перспективе једног дечака допреће само до деце и осетљивих, рекло би се до оних који, како их карактерише Горан Петровић у својој Ситничарници Код срећне руке, имају способност потпуног читања.

Следећа битна ствар јесте то што ову књигу отвара добро познат текст под насловом $C$ јесени, када почну ветрови. Врло је важно проверити утиске ученика приликом коментарисања овог текста, јер се у литератури наглашава његова, већ поменута, изразито лирска компонента и, већ насловом наговештена, ,ритмичка структура блиска стиху” (ДЕЛИЋ 1997: 71). Оваква „увертира” на веома суптилан начин уводи тему дивљих кестенова која је присутна и у наредном тексту, а ту су и битни мотиви као што су: белег на челу, звезда, игра, породица... Један од важних момената јесте и присуство јаких мириса који одају чулну осетљивост дечака, иако се чини да приповедање не тече из његове перспективе. У каснијим текстовима ће се она развити у доминантно дечаково обележје. Већ овде је могуће искористити исечак из интервјуа Живот, литература. Кишов саговорник инсистира на пишчевом повратку у детињство, на утисцима које он из њега носи, на сећањима која се тичу његових родитеља, времена и простора у коме је његова породица живела. На питање о првим својим импресијама из детињства Киш одговара:

„Prve čulne impresije mog detinjstva potiču iz Novog Sada, koji se nalazi nekih sto kilometara južnije od Subotice, niz Dunav. ${ }^{4}$ Mirisi, ukusi, boje. Mirisi kestenovog cveta, ruže u vazi, kamilice, mašinskog ulja u mehanizmu šivaće mašine, očeve cigarete, kolonjske vode na vratu moje majke, čiste krevetnine, mokraće, mušeme na stolu, kafe, sapuna, začina, kožne trake na očevom šeširu, sedišta fijakera, železničke stanice, apoteke, praznog kupea prve klase, remena za podizanje prozora u vagonu, kožnog kofera. Ukus ribljeg zejtina, meda, bele kafe, cimeta,

\footnotetext{
${ }^{4}$ Данило Киш је рођен у Суботици.
} 
drvenih bojica, lepka, mastila, hartije, kaučuka, bombona, krvi iz prsta, jodne tinkture, suza, sirupa protiv kašlja. Boje kestenovog lista: tamnozeleno lica i bledozelno naličja, vatromet kaleidoskopa, prelivi duge u klikerima-staklencima, ruj venjenja, nebesko plavetnilo, belina oblaka, prljavožuto kućnih fasada. I slike, kao kad se prelistavaju stare razglednice: arteski bunar na uglu ulice, zimi obložen slamom; drvored kestenova čiji prevrtljivi listovi preteće šume pred oluju; prizemne kuće koje gledaju na dvorišta; niski prozori sa bledoružičastim i jarkocrvenim cvetovima geranijuma; prašnjavi travnjak pred kućom; škripava špediterska kola i zaljuljani fijakeri koji plove ulicom kao gondole; sirotinjska dvorišta; vešplav koji se rastvara u vodi limenog korita ispred vešernice; slivnik što zaudara na trulež i u koji se cedi sapunjava voda; kasarna i groblje; katedrala i sinagoga; pravoslavna Uspenska crkva u kojoj me u petoj godini krste (sveštenik mi sipa vodu na teme, ja tražim pogledom svoju majku koja me začas prepustila brizi krsnoga kuma; miris tamjana, zapevanje svštenika, treperenje sveća, lica svetaca na ikonama); tramvaji sa lirom; fotografski atelje sa veštačkim cvećem i sa pravom pticom u kavezu; čipka iznad sedišta od baršuna u kupeima prve klase; majčina singerica nalik na katedralu" (KIŠ 2007: 239, 240).

Та прва сећања Данила Киша су очигледно повезана са сећањима Андреаса Сама који се у следећем тексту, назовимо га и првим поглављем романа или првом причом збирке, под називом Улица дивљих кестенова, појављује као одрастао човек. Међутим, поред тих, рекло би се, крајње пријатних успомена, Данило Киш помиње и неке од негативних тренутака које памти из најранијих дана, а који су јако битни за развитак фигуре оца у његовим делима. Ученицима је то могуће прочитати, али и пустити видеоснимак у коме писац сам говори о такозваним „хладним данима”, за чији назив тврди да је „само еуфемистичка метафора иза које се крије барбарски покољ војвођанских Срба и Јевреја". Тиме се успоставља и историјски оквир описаних збивања. Након тога, а пре наставка даљег разговора о Раним јадима, требало би питати ученике за њихова прва сећања, за њихове чулне импресије које их и данас могу вратити у најраније детињство. Та мала дигресија би их макар за један корак могла приближити Андреасу Саму и његовом творцу.

Поменути мотиви белега и звезде такође су важни, и то важни као двоструки симболи. С једне стране звезда је „судбински биљег, и то, прво, биљег дара који сви не поседују, већ само одабрани имају своју звезду и слиједе је” (ДЕЛИЋ 1997: 72), а с друге стране звезда се може повезати са Давидовом звездом, односно знаком јеврејства, који Кишову породицу погубно обележава у периоду Другог светског рата.

Мотив звезде повезан је и са мотивом породице коју упознајемо у наставку. Одрасли Андреас Сам се враћа у улицу у којој је некада са својом породицом живео, а која му је остала у живом сећању захваљујући дрвореду дивљих кестенова којих сада више нема. Поред помињања дивљих кестенова од стране Данила Киша, као и Бемове улице у којој је заиста живео, а на коју 
наилазимо у неком од каснијих његових одговора, те исте кестенове срећемо и у разговору Андија са својом учитељицом госпођом Риго у радио-драми Hoћ и магла, коју су ученици имали задатак да одслушају пре часа. Све то говори о овом делу природе као доминантном детаљу улице у којој је породица Сам некада живела. Тема дивљих кестенова послужила је писцу да дискретно унесе у ове редове и проблематику која се тиче успомена. Иако „од кестенова... нема ни трага”, јер „кестенови немају своје успомене” (КИШ 2013: 9), Андреас Сам има и спреман је да крене у потрагу за изгубљеним временом, како би доказао да баш оне - успомене - нису „дим, пара, сан, магла, ништа", како то тврди муж Андијеве учитељице у драми Ноћ и магла.

У поглављу/причи Игра развија се мотив породице и јасно се смењују перспективе, а актери догађаја се разоткривају постепено. Приказана је игра малог Андреаса која добија двоструко тумачење, а као додатни мотив се уводи мотив лутајућег Јеврејина преко Андијевог деде по оцу, који је био трговац гушчијим перјем. На питање о томе ко су били његови преци са очеве стране, Киш одговара: „Na osnovu aluzija u pismima moga oca, njegovi su preci dospeli u Mađarsku kao trgovci guščijim perjem, po svoj prilici iz Alzasa, odakle su bili proterani" (KIŠ 2007: 248). Још једном имамо биографску чињеницу уткану у књижевно дело, али модификовану и подигнуту на један виши симболички ниво. Услед дечакове игре, испољава се јеврејско порекло са очеве стране упркос мајчиној уверености да тога нема, јер „њен Плави Дечко” физички личи на њу, а кроз поредбену реченицу да „као да лута кроз векове", Андреас нуди муштерије гушчјим перјем идући од слике до слике (КИШ 2013: 11), види се да дечак није само реинкарнација Макса Ахашвероша, него и митског лутајућег Јеврејина, који је због неверовања у Исуса Христа и његовог исмевања, осуђен да лута светом до Другог Христовог доласка, осуђен, поред лутања, и на патњу. Та осуда коју је непобожни Јеврејин навукао на себе, одразиће се на његове потомке, на друге Јевреје, на породицу Андреаса Сама, чији ће отац бити одведен у логор за време Другог светског рата из кога се никада неће вратити.

Та фигура оца која је у поглављу/причи Улица дивљих кестенова само наговештена, сада бива скицирана, па би због тога било занимљиво показати ученицима слику малог Киша са својом породицом, где је Едуард Киш приказан са наочарима које се често помињу као саставни део физичког портрета Едуарда Сама, са косом раздељеном по средини, што се такође среће у његовом опису у поглављу/причи Човек који је долазио из далека. Наочаре се помињу и приликом његовог посматрања Андијеве игре кроз кључаоницу.

За разлику од дечака који своју игру сматра безазленом, Едуард Сам у њој види доказ који потврђује да је Анди његова крв, а Марија трагично подсећање на дубински узрок њихове породичне несреће. Бајка којом се ова повест завршава стоји као пандан дечаковој игри и у вези је са коментаром 
који Киш даје о својој мајци, а који је такође део интервјуа Живот, литература:

„Moja je majka zaista znala mnoge bajke i legende, a praznine u svom pamćenju dopunjavala je (u Mađarskoj zabiti, bez ijedne srpske knjige) iz glave, podešavajući stvari tako da budu najbliže zaboravljenom izvorniku, ili improvizujući na zadatu temu sa velikim odstupanjima: neka su njena pesnička rešenja bila odveć primenjiva na naš život, na našu sopstvenu situaciju a da bih poverovao da su verna originalu. Ili je to bila samo pogreška mog rasuđivanja; možda sam samo, pri tom svom prvom susretu sa poezijom, otkrio, sa pogrešnom premisom, suštinu poezije: da ona uvek govori o onome ko je čita i sluša" (KIŠ 2007: 245, подвукла Д.С).

У вези са овом бајком битно је истаћи још нешто: „У причи је убијен онај ко је извор „тамне”, ,неплемените” крви - царица - што је бајколик, али довољно језив наговештај Едуардове судбине и догађаја у времену ратне апокалипсе који су се обрушили на оне који нису 'чисте крви' ” (ДЕЛИЋ 1997: 88). Други светски рат који је више позадина описаних догађаја него доминантна тема романа/збирке приповедака, увукао се ипак у дечакову свест, трансформишући се у константан страх од опасности која је претила његовом оцу. Поглавље/прича Серенада за Ану, иако већ својим насловом сугерише да је у питању пријатан догађај, почиње реченицом: ,Чуо сам неки жагор под прозором и помислих да су дошли да убију мог оца” (КИШ 2013: 25). Међутим, већ у следећој реченици, захваљујући звуку виолине, дечак се ослобађа страха. На пријатан и духовит начин описана је серенада за Ану, а акценат је још једном стваљен на веома истанчано дечаково чуло мириса, jep је управо по мирису познао да је цвеће остављено на прозору за његову сестру убрано из баште учитељице госпође Риго.

Поред Серенаде за Ану, у поглављима/причама као што су Погром, Прича од које се чрвени, Замак осветљен сунцем, Ливада, Докму биштукосу, Мачке, Крушке, Коњи, Дечак ипас, Еолскахарфа лик Едуарда Сама је одсутан, „и то до те мјере да се празнина његовог непостојања осјећа, да је готово присутан својом одсутношћу" (ДЕЛИЋ 1997: 134). У Причи о печуркама се јавља негативно окарактерисан као „луди отац”, а у Веренищима је приказан у времену у коме није пио, у времену у коме Андреас још увек није радио код сељака. Ове појединости расветљавају и личност Едуарда Киша и лик Едуарда Сама. У константној тензији између ова два бића стоји потреба да се они домишљају, допуњују и испуњују чврстом материјом маште како би се некако открили на породичном групном снимку, у позадини. На једној од „слика” из баршунастог албума видимо Едуарда Сама као некога ко страда у понижењу, јауче и пада, док га храбре и подижу жене, а затим са те слике ишчезава без објашњења.

Иако отац на тај начин нестаје из физичког света, остаје његова сенка која не напушта породицу ни у једном тренутку. Та сенка је присутна било онда када 
Андреас говори о очевим документима које са собом носи, као што су писмо упућено сестри Олги и Кондуктер чији је творац био Едуард Сам, било када помиње офуцане перјане јоргане које мајка сматра симболима Андијевог и Аниног детињства и њене љубави према њима, а у ствари одаје судбину лутајућег Јеврејина чврсто зашивену за поставу дуња. Породица Сам на своја леђа товари „тешко, наследно бреме” (КИШ 2013: 78). Једино што остаје за њима јесу Андијеве успомене на пса Динга, прву љубав Јулију Сабо, другове, учитељицу, понижавајуће послове и немаштину у којој су живели, успомене које се никако не могу окарактерисати као „ноћ и магла”. Па ипак, чињеница да су успомене изграђене од детаља који временом ишчезавају узрок је фрагментарности која за собом повлачи немогућност прецизног жанровског одређења. Исцепканост и одсуство хронологије у њеном основном значењу догађаја који претходе једни другима и следе једни за другима, утицаће на мишљење по коме се Рани јади могу назвати збирком прича. С друге стране, обједињене темом потраге за самим собом, која прераста у потрагу за ишчезлим оцем, као и ликом Андреаса који је најчешћи, директни или индиректни, приповедач, али и захваљујући каузалности која ипак успоставља одређену хронологију у описаним догађајима, те приче прерастају у поглавља кратког романа.

Ликови Едуарда и Андреаса Сама постепено се развијају у наставку породичне трилогије и доживљавају кулминацију у последњој њеној књизи, која, као и њена претходница, јесте недвосмислено роман. С обзиром на то да ученици као лектиру имају само Ране јаде, разговор о њој и њено смештање у шири контекст породичног циклуса могао би да послужи као подстрек за даље читање и наставак трагања.

Овакав приступ Раним јадима би захтевао више од 45 минута које нуди школски час, чак можда и цела два часа. Да би се употпунио доживљај, ученицима би се, у зависности од могућности и времена, могла пустити позоришна адаптација Раних јада од стране суботичког Народног позоришта која постоји на Јутјбу, а као домаћи би добили задатак да одговоре на тему Андреас Сам као двојник Данила Кима.

\section{6. Закључак}

Наша сећања из детињства, сматра Фројд, ,, ne bivaju fiksirana u trenutku doživljaja i onda ponavljana, kao što je to slučaj sa svesnim sećanjima iz zrelog doba, već se, izmenjena, falsifikovana, stavljena u službu neke kasnije težnje, izvlače tek u docnijem dobu, kada je detinjstvo već prošlo, tako da se ne mogu više strogo odeliti od fantazija" (FROJD 1976: 129). Фантазија тако повратно храни живот, не само литературу.

Данило Киш је своја прва сећања и своје прве фантазије преточио у литературу, у кратке прозне форме које добијају метафизички карактер 
и прерастају у универзална питања сведена на личну несрећну судбину. Због тога није увек могуће повући црту између њега и његових књижевних јунака, јер они стоје у чврстој симбиози. Могућност прилажења Андреасу Саму као Кишовом двојнику доказ је који ту тезу потврђује.

Читање Раних јада у аутобиографском кључу само је један од могућих приступа у тумачењу овог дела. Примењен на адекватан начин, он ученицима даје могућност да приђу и Данилу Кишу и Андреасу Саму које опседају готово исте теме и муче готово иста сећања. Чије су заправо успомене аутентичне, ученици ће добити шансу да сами процене.

\section{Цитирана литература}

ДЕЛИЋ, Јован. Кроз прозу Данила Киша: Ка поетици Кишове прозе II. Београд: БИГЗ, 1997.

КИШ, Данило. “Књижевне чињенице” <https://www.youtube.com/watch? $\mathrm{v}=\mathrm{c} 2 \mathrm{nWD} \_$Sbuxs $>11.11 .2019$.

FROJD, Sigmund. Iz kulture i umetnosti. Novi Sad: Matica srpska, 1976.

KIŠ, Danilo. Gorki talog iskustva. Priredila Mirjana Miočinović. Beograd: Prosveta, 2007.

KIŠ, Danilo. "Izvod iz knjige rođenih". <https://www.youtube.com/watch? $\mathrm{v}=Y 9 \mathrm{kUvZYEK68>}$ 26. 6. 2018.

KIŠ, Danilo. "Uspomene, sećanja” (1/8). <https://www.youtube.com/watch? $\mathrm{v}=\mathrm{CP} 3$ nylnyico\& $\mathrm{t}=151 \mathrm{~s}>11.11 .2019$.

MILENKOVSKI, Saša. "Rani jadi”. Subotica: Narodno pozorište, 1991. <https:// www.youtube.com/watch?v=lw7q4K0xxI0\&t=1387s $>28.6 .2018$.

Извори

КИШ, Данило. Рани јади. Београд: Архипелаг, 2013. 
Danica S. Sladojević

\section{THE AUTOBIOGRAPHICAL APPROACH IN THE EDUCATIONAL INTERPRETATION OF EARLY SORROWS BY DANILO KIS}

The aim of this paper is to offer a different theoretical framework for the educational interpretation of Danilo Kis's novel Early Sorrows. Existing approaches, which are undoubtedly valuable, have lost their originality and thus a new interpretation method might shed a different light on this masterful piece of art. The plenty of facts from Kis's life are woven into the childhood memories of the novel's main character Andreas Sam, who as an adult takes a walk down the memory lane. Whom do the memories belong to? Are they the author's, the character's? Is it possible for an author to maintain the neutral position once he „borrows” his own recollections of the bygone times and personal life to his character? Those are some of the questions this paper will try to give answers to, hoping it can encourage the students to take somewhat philosophical stance.

Keywords: educational interpretation of novel, the autobiographical approach, Danilo Kis, Early sorrows 